\title{
Draft guidelines for publishers of conference proceedings
}

\author{
Prepared by the STS Ad Hoc Committee on Designing \\ a Conference Proceedings Style \\ Dorothy McGarry, Chair
}

\section{Recommendations that could improve bibliographic access to scientific and technical conference proceedings.}

\begin{abstract}
E Lditor's Note: These guidelines are in draft form only. The Committee welcomes any comments or suggestions from the library community and other interested parties. If approved, the guidelines would then be sent for publication to journals issued by various associations that publish conference proceedings, and to editors within the associations, urging them to follow the guidelines. Annoucements about the guidelines would also be sent to various library journals. Your comments may be addressed to Dorothy McGarry, P.O. Box 5803, Sherman Oaks, CA 91413.
\end{abstract}

Published proceedings of conferences are very important in research. It is often difficult, however, for people to locate the proceedings of a particular meeting. Often, the title pages of these proceedings are confusing in their layout, or the title pages contain insufficient information for identifying a particular conference. This is critical because the title page is the established standard source for information used to catalog a book. The librarians who catalog the book and the library users who request it may not be sure what the title is intended to be, or who published the book, or even what the name of the meeting is. This confusion and uncertainty make it difficult for library users to know how to cite the book or how to look for it in a cata$\log$.
Those who prepare and publish conference proceedings could contribute to the usefulness of the conference literature by applying the following guidelines.

\section{Title page}

The title page should include:

A clearly indicated title.

Examples:

Microcomputer software.

Modern problems of surface physics.

Clearly indicated information beyond that of the title itself, including information such as the name of the meeting if it had a name.

Example:

Proceedings of the Working Conference on Circulation, Neurobiology, and Behavior, held October 4-7, 1981, in Dallas, Texas, U.S.A.

The relationship of the book to the conference should be indicated on the title page.

Examples:

Proceedings of the 23rd IEEE Conference on Decision \& Control.

Selected papers from the Workshop on...

Layout and typography can assist in identifying the various elements of information required.

Include the number of the meeting if any, and the place and the date the meeting was held. 
Names of sponsoring organization(s), with an explicit statement such as "sponsored by" or "organized by."

An explicit description of function with the name(s) of the editor(s), such as "edited by" pr "chairman/editor."

Series statement, if the publication is part of a series, with clearly indicated series title and numbering.

Place(s) of publication, name(s) of publisher(s), and date(s) of publication.

Confusion can arise depending on how information appears on the title page; i.e., the initials of the conference may appear at the top of the page followed by the name of the conference or "Proceedings of the..." followed by words which might actually be the book's title meant by the publisher or the editor. A library may choose a title the publisher or editor didn't intend when describing the book in a catalog, not being sure which of the parts was meant to be a title. The library user may come up with two different citations for the same conference, perpetuating problems in retrieval. As an example:

Proceedings of the Workshop on Geological Disposal of Radioactive Waste (top of page).

In Situ Experiments in Granite (middle of page).

This might result in one cataloger putting as the title "Proceedings of the..." and another using "In situ experiments in granite." In this case, the title on the front cover was "Geological disposal of radioactive waste," which could add to the confusion over what the title was meant to be.

All information on the title page should be consistent with information on the cover and spine; titles should not differ from cover to title page, nor should the name of the meeting nor the title of the series differ from location to location within the book.

\section{Back of the title page}

The back of the title page should include:

Name and address of distributor, if different from publisher, with an explicit statement of function; e.g., "distributed in the U.S. by," or "available from."

Copyright information.

\section{Miscellaneous}

Number the pages consecutively if possible.

If the name of a corporate body is placed on the title page, provide it with some explanation of the relationship of that body to the conference or to the publication; e.g., published by, sponsored by, organized by, supported by.

Catalogers attempt to determine, when checking a conference publication, whether the conference is "named" or "unnamed." A book whose title page reads Semiconductor physics: Proceedings of an International Conference would not be considered to be the proceedings of a "named" confer- ence, while Proceedings of the International Conference on Semiconductor Physics would lead to access under the name "International Conference on Semiconductor Physics." In the first case, "an international conference" is taken to be a purely generic description; in the second case, "the International Conference on..." indicates a specifically named event.

In cases where different forms of a conference name appear in different locations, the cataloger must determine whether the name of the conference is, e.g.:

Computer Society Conference on Artificial Intelligence Applications (title page)

Conference on Artificial Intelligence Applications (cover)

IEEE Computer Society Conference on Artificial Intelligence Applications (preface)

While in some situations this might not matter much, in putting a record for this work into a cata$\log$ for patrons' and librarians' use it is important to remember that the record could appear in any one of three different locations in the catalog. Furthermore, if the conference is one in a series of similar conferences, and each year there is a change in the order of the words in the name, such as Condensed Matter Physics Symposium (first year), Symposium on Condensed Matter Physics (second year), the records for these conferences will not appear next to each other in the catalog and the works will not appear next to each other on the shelves.

The name of the conference, if it has one, should appear clearly on the title page, back of the title page, pages before the title page, the cover, or the spine in order for provision of clear and primary access to that name in bibliographic records; librarians would appreciate it if it actually appeared on the title page. If the name of the meeting does not appear in any of the places mentioned above, access to the name of the conference on a record would depend on whether the cataloger noticed the name elsewhere (e.g., in the preface or introduction) and whether a note and an additional access point were made. Of course, if the meeting has no name as far as the conference arrangers are concerned it is not necessary to create one; if one is used it should be the same in all locations in the book.

"Volume" and "edition" have very specific meanings in libraries. "Volume 2," for example, should not be used for the second conference in a sequence, but only for a separate physical unit for the same conference. Volume usage only for multiple volumes within the same conference year rather than in relation to the number of the conference would reduce confusion. A statement that calls something a "second edition" should refer to the same text reworked or reset, not to totally new text. Proceedings of a second conference would not, therefore, be either a "second edition" or a "volume two" of the first conference.

Although librarians are among the primary collectors of conference proceedings, catalog records 
for these proceedings appear in machine-readable databases which make the information available to millions of library users. Proper access to these proceedings makes them more valuable to the scientific, academic, and business communities. With the help of those who prepare and publish conference proceedings library users will be able to locate and use those proceedings more efficiently.
Members of the Ad Hoc Committee that prepared these guidelines are: Dorothy McGarry (chair), University of California, Los Angeles; Grace Agnew, Georgia State University; Carol Cubberley, University of Central Florida; Edward D. Garten, Tennessee Tech University; Sara Shatford, University of California, Los Angeles.

\section{ACRL list of materials available}

\section{A complete checklist of ACRL publications in print.}

\begin{abstract}
$\mathrm{S}_{\mathrm{i}}$ Def standards and guidelines are free. Other publications are priced as listed. To ensure that your order is properly processed, include ISBN, author, title, list price, and applicable discount for each item ordered.

Both institutions and individuals may order on account, plus postage and handling; however, prepayment should accompany individuals' orders of $\$ 15.00$ or less. No postage or handling charges are added to prepaid orders (check, money order, credit card). All prices are payable in U.S. funds. The first price stated is list price.
\end{abstract}

ISBN prefix: 0-8389-.

\section{Discounts}

ALA personal and organizational members are eligible to receive a ten percent (10\%) discount on ACRL materials (except subscription items). To receive the discount, give your membership number, and deduct the discount when preparing your orders.

ACRL personal and organizational members receive an additional 20-30\% discount on ACRL materials. Look for the ACRL member prices on this list.

Quantity discounts are available when five or more copies of the same title are ordered to be shipped to the same address. Inquire for prices on specific titles.

\section{Handling charges}

Invoice amounts of $\$ 20.00$ or less, $\$ 1$.

Invoice amounts of $\$ 20.01-\$ 50.00, \$ 2$.

Invoice amounts of $\$ 50.01-\$ 100.00, \$ 3$.

Invoice amounts of $\$ 100.01-\$ 200.00, \$ 4$.

Invoice amounts greater than $\$ 200.00, \$ 5$.

Send orders to: ALA Order Dept., 50 E. Huron Street, Chicago, IL 60611-2795. Free ACRL publications may be ordered from ACRL/ALA at the same address.

\section{ACRL standing order plan}

This plan guarantees that you will automatically be sent all new ACRL publications costing less than $\$ 30$. For details, contact Mary Ellen Davis at the ACRL Office, (312) 944-6780.

\section{Bibliographic instruction}

-Back to the Books: Bibliographic Instruction and the Theory of Information Sources (1983). Papers presented at the Bibliographic Instruction Section program at the 1982 ALA Annual Conference. Edited by Ross Atkinson. 76p. 6587-3. \$15; ACRL members $\$ 12$.

- Bibliographic Competencies for Education Students (1981). Prepared by the Education and Behavioral Sciences Section's Bibliographic Instruction for Educators Committee. Provides ex- 